\title{
Hydrogen solubility of shale oil containing polar phenolic compounds
}

\author{
Zachariah S. Baird ${ }^{a}$, Petri Uusi-Kyyny ${ }^{b,}{ }^{,}$, Vahur Oja ${ }^{a}$, Ville Alopaeus ${ }^{b}$
}

\begin{abstract}
Many refineries use hydrogen to upgrade heavy fuel feedstocks, and therefore, hydrogen solubility is an important parameter. Shale oil is a fuel for which hydrotreatment is of interest, but no data about its hydrogen solubility can be found in the literature. This article presents experimental data for the hydrogen solubility of two shale oil samples measured at high temperatures and pressures (423 to $527 \mathrm{~K}$ and 40 to $140 \mathrm{bar}$ ). Experiments were performed using a continuous flow apparatus. Results show that the shale oil had a lower hydrogen solubility than most other fuels, probably due to the high content of polar phenolic compounds in the oil. Removing about $80 \%$ of the phenolic compounds increased the hydrogen solubility by approximately $0.1 \mathrm{~mol} \mathrm{H}_{2} / \mathrm{kg}$ oil (which is about 15 to $45 \%$, depending on the solubility). Analysis also showed that current prediction methods used for petroleum and coal liquids cannot reliably be used for predicting the hydrogen solubility of this shale oil and other similar fuels.
\end{abstract}

Keywords: hydrogen solubility, shale oil, hydroxyl group, unconventional fuel, phenolic, phase equilibria

This document is the Accepted Manuscript version of a Published Work that appeared in final form in Industrial and Engineering Chemistry Research, copyright (C) American Chemical Society after peer review and technical editing by the publisher. To access the final edited and published work see https://pubs.acs.org/doi/abs/10.1021/acs.iecr.7b00966

\section{Introduction}

Hydrotreatment processes are commonly used to upgrade fuels, especially heavy fuels and fuels containing unwanted heteroatoms. The hydrogen solubility is needed for designing and operating these processes because the concentration of hydrogen in the liquid phase is important for reaction kinetics ${ }^{1}$ and for accurately determining the material balance for hydrogen across a chemical plant ${ }^{2}$. Experimental data for hydrogen solubility exists for a number of pure compounds ${ }^{3}$, including polar oxygenated compounds such as phenols ${ }^{4,5}$, alcohols ${ }^{4,6-26}$, ketones ${ }^{7,27-29}$, esters ${ }^{30,31}$ and organic acids $s^{7,11,31}$. Data also exists for many different fuels, including heavy oil samples ${ }^{32-35}$, straight run gasoil ${ }^{36}$, naphtha reformate $^{37}$, light naphtha ${ }^{38}$, coal liquids ${ }^{39-45}$, creosote oil ${ }^{46}$ and bio oils ${ }^{47-50}$. Data was also found for white oils ${ }^{51,52}$. We compiled the literature data on fuels from most of these sources into a single spreadsheet that can be found on the Open Science Framework page for this research project (https://osf.io/dhkew/). However, no information could be found about the solubility of hydrogen in shale oils, even though shale oil is a fuel for which hydrotreatment would be of interest due to its high content of heteroatoms and aromatic compounds.

Shale oil is an unconventional liquid fuel produced from solid oil shale via pyrolysis ${ }^{53,54}$ (not to be confused with tight oil ${ }^{55}$, which is conventional oil trapped inside a shale or sandstone formation). Shale oil has received attention due to the large quantities of oil shale present in deposits around the world ${ }^{56}$. It has been estimated that $4.7 \cdot 10^{12}$ barrels of oil could be produced from these resources ${ }^{57}$, but

\footnotetext{
a Department of Energy Technology, Tallinn University of Technology, Ehitajate tee 5, 19086 Tallinn, Estonia

${ }^{\mathrm{b}}$ Department of Chemical and Metallurgical Engineering, Aalto University, P.O. Box 16100, Fl-00076 Espoo, Finland

* Corresponding author: petri.uusi-kyyny@aalto.fi, +358 504348969
} 
economic and environmental challenges have limited its production. And yet, shale oil industries exist in several countries, including Brazil, China and Estonia. Hydrotreating processes could help solve some of the challenges with shale oil by removing pollutants like sulfur and nitrogen and by increasing the economic value of the fuel. Indeed, a fair amount of research has been done on hydrotreating shale oil ${ }^{58-}$ ${ }^{66}$, and Eesti Energia, a company which produces shale oil, has done preliminary investigations with the goal of incorporating a hydrotreating unit into their shale oil plant ${ }^{67}$. Data on the hydrogen solubility of shale oil would be important for research and design work done in this field.

It is important to note that the composition and properties of shale oil can vary widely depending on the oil shale and retorting conditions used ${ }^{56,68-70}$. Often shale oil contains significant amounts of olefins, aromatic compounds and heteroatoms, which make it compositionally different from conventional petroleum fuels. For example, shale oil produced from Kukersite oil shale (Estonia) contains large amounts of phenolic compounds ${ }^{71,72}$. From experimental data for pure compounds ${ }^{3}$, it can be seen that, in general, the presence of a polar oxygen-containing functional group decreases the hydrogen solubility of a compound. For instance, at $298 \mathrm{~K}$ and about 100 bar the hydrogen solubility of hexane is $1.14 \mathrm{~mol} \mathrm{H} / \mathrm{kg}^{16}$, but for hexanol it is only $0.309 \mathrm{~mol} \mathrm{H}_{2} / \mathrm{kg}^{22}$. Because compositional differences affect the properties of the shale oil, many of the correlations developed using petroleum do not provide accurate results for these shale oils. This makes experimental data even more essential for shale oils, and only a limited amount of experimental data exists about the properties of shale oils ${ }^{73}$.

This work presents the first known experimental data for the hydrogen solubility of shale oil. Experiments were performed at high temperatures and pressures, which are the conditions relevant for industrial plants. Additionally, a second sample of the shale oil was measured for which many of the phenolic compounds had been removed, which allowed the influence of these compounds to be examined. The applicability of using existing solubility prediction methods with this shale oil is also evaluated.

\section{Experimental Methods}

\subsection{Sample preparation}

The shale oil used in this study was obtained from Eesti Energia's Narva Oil Plant (Narva, Estonia). Kukersite oil shale (Estonia) is used as the raw material for the retort. The plant uses a solid heat carrier retort (also known as the Galoter process) ${ }^{74}$. The shale oil is separated into three wide industrial fractions at the plant: shale gasoline, fuel oil and heavy oil. Even though the heavy oil fraction is the one most likely to be hydrotreated, a fuel oil sample was used because it could be measured without needing to dilute it with a solvent. Heavy samples need to be diluted to lower their viscosity and enable light to pass through, but then the more complex heavy oil + solvent + hydrogen system must be modeled, which would require significantly more research to develop appropriate models for the heavy shale oil.

As mentioned, Kukersite shale oil contains high quantities of phenolic compounds. To study the impact of those polar phenolic compounds on the hydrogen solubility, the fuel oil was split into two portions and the phenolic compounds were removed from one of the portions using extraction. The basic procedure is described in detail elsewhere ${ }^{71,75}$, and involves extraction with $10 \% \mathrm{NaOH}$, washing with distilled water and drying the oil. Extraction was carried out in a glass cone with a volume of 5 liters that was fitted with a stopcock made of glass and teflon (see Figure 1). $2881 \mathrm{~g}$ of shale fuel oil was poured into the cone. A glass stirrer was inserted into the cone from above, which was turned using a motor. Then the $\mathrm{NaOH}$ solution was slowly added from the top of the cone using a peristaltic pump. The cone was allowed to fill, and then the $\mathrm{NaOH}$ with the extracted phenols was periodically removed from the bottom through the stopcock. 


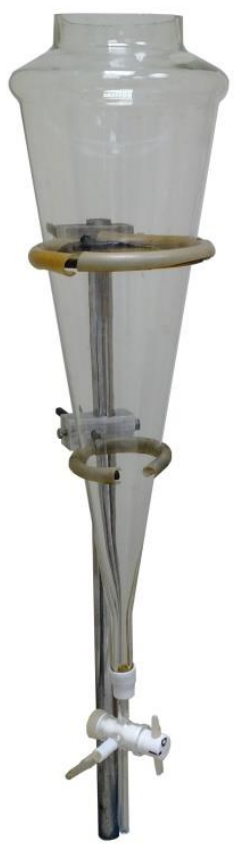

Figure 1. Picture of the liquid-liquid extraction vessel.

Approximately $12.5 \mathrm{~L}$ of the $\mathrm{NaOH}$ solution was sent through the oil, and at the end the water phase was translucent with an orange tint. Then about $5.5 \mathrm{~L}$ of distilled water was sent through the oil in the same manner to wash out any remaining $\mathrm{NaOH}$. Distilled water was pumped in until the water removed from the device had a $\mathrm{pH}$ of 7 . Some of the oil had been removed with the $\mathrm{NaOH}$ solution and had separated to the top of the container where the used $\mathrm{NaOH}$ had been placed. This oil was removed from the top and placed back in the extraction device by itself (the other oil had been removed first). $2 \mathrm{~L}$ of $10 \% \mathrm{NaOH}$ was added to ensure that any phenols were removed from this additional oil, and then $8 \mathrm{~L}$ of distilled water was used to wash the oil. This oil was combined with the portion extracted first and then the oil was left to stand overnight to allow more of the remaining water to separate out of the oil. Then the oil was dried further by adding sodium sulfate salt to absorb water in the oil. The dried oil was then poured through a filter to ensure that the salt crystals were removed from the oil. $949 \mathrm{~g}$ of the fuel oil was left after extraction. Note that losses occurred during extraction and filtering, and therefore, the amount of recovered oil cannot be taken as an accurate representation of the amount of phenolic compounds in the oil.

Properties of both the fuel oil and dephenolated fuel oil samples are given in Table 1, and details about the measurement methods used can be found in the next section. Infrared spectra are presented in Figure 2, and files containing the spectral data can be found at https://osf.io/dhkew/.

Table 1. Properties of the shale oil samples used in this study.

\begin{tabular}{l|cc}
\hline & Fuel oil & Dephenolated oil \\
\hline Density at $293 \mathrm{~K}\left(\mathrm{~g} / \mathrm{cm}^{3}\right)$ & 1.0170 & 0.9682 \\
Refractive index at $293 \mathrm{~K}$ & 1.5567 & 1.5411 \\
Molecular weight $(\mathrm{g} / \mathrm{mol})$ & 242 & 250 \\
Hydrogen content $(\mathrm{wt} \%)$ & 9.4 & 10.7 \\
Carbon content $(\mathrm{wt} \%)$ & 80.9 & 82.5
\end{tabular}




\begin{tabular}{l|cc} 
Atomic $\mathrm{H} / \mathrm{C}$ ratio & 1.38 & 1.55 \\
Hydroxyl group content (wt\%) & 5.3 & 1.1 \\
Hydroxyl groups per molecule & 0.75 & 0.16 \\
Density at $313 \mathrm{~K}\left(\mathrm{~g} / \mathrm{cm}^{3}\right)$ & 1.0026 & 0.9542 \\
Density at $333 \mathrm{~K}\left(\mathrm{~g} / \mathrm{cm}^{3}\right)$ & 0.9880 & 0.9399 \\
Density at $353 \mathrm{~K}\left(\mathrm{~g} / \mathrm{cm}^{3}\right)$ & 0.9733 & 0.9254 \\
Volumetric expansion coefficient & 0.0007166 & 0.0007371 \\
\hline
\end{tabular}

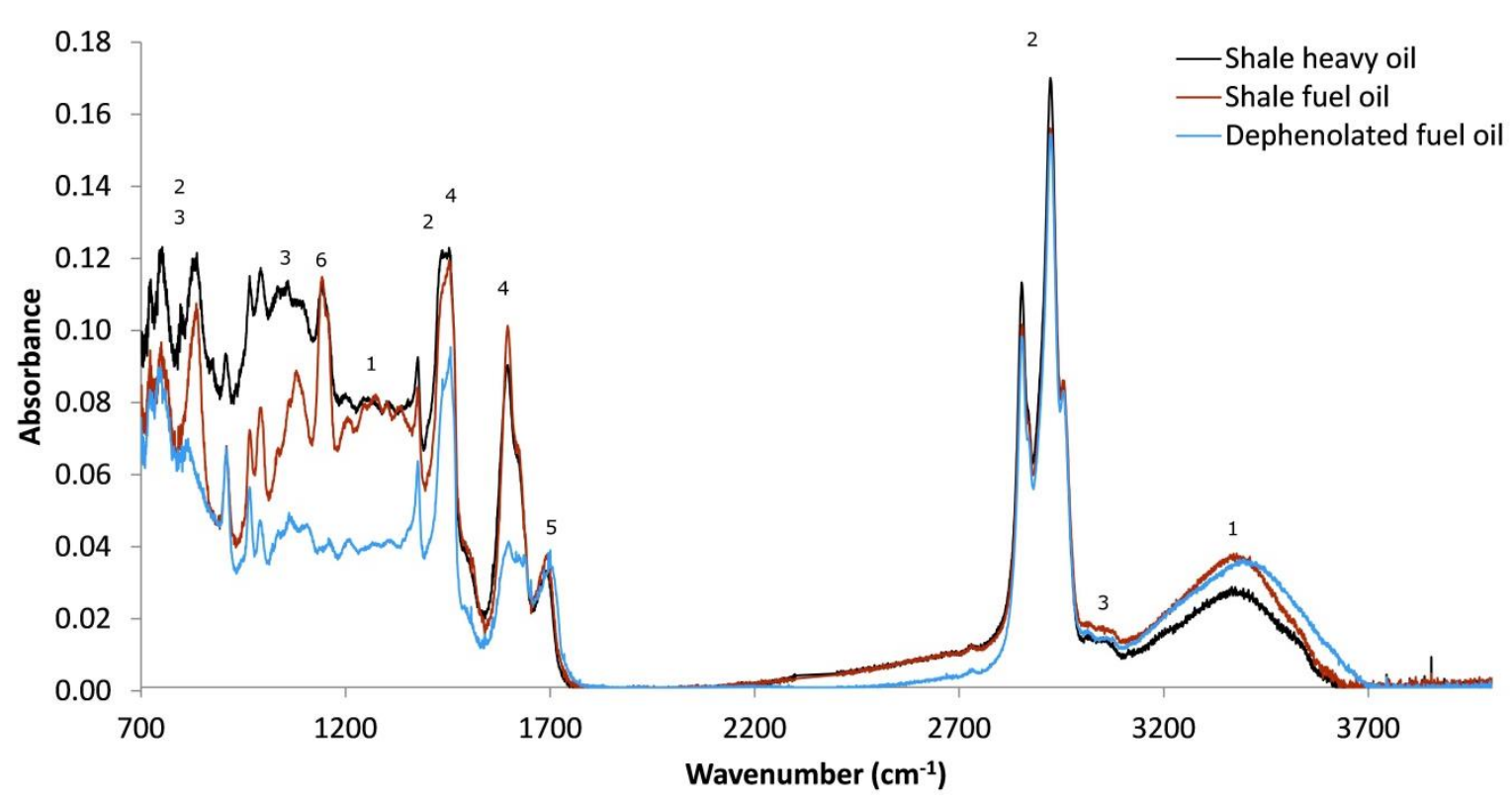

Figure 2. Infrared spectra of the shale oil samples measured in this study and a heavy shale oil sample (for comparison). The numbers denote the main functional groups associated with a given region ${ }^{76}$ : (1) $\mathrm{O}-\mathrm{H}$, (2) saturated $\mathrm{C}-\mathrm{H},(3) \mathrm{C}-\mathrm{H}$ for aromatic and double bonded carbon, (4) carbon bonds in an aromatic ring, (5) $C=O$, (6) $C-O$.

\subsection{Measurement of characteristic properties}

Characteristic properties of the shale oil samples were measured, and are presented in Table 1. Infrared spectra were also measured, as well as densities at higher pressures.

\subsubsection{Density}

Densities were measured using a DMA 5000M density meter (Anton Paar GmbH, Graz, Austria) and had a standard uncertainty of $0.00015 \mathrm{~g} / \mathrm{cm}^{3}$ (expanded uncertainty of $0.0003 \mathrm{~g} / \mathrm{cm}^{3}$ at the $95 \%$ level). The density was measured at 293, 313, 333 and $353 \mathrm{~K}$, and volumetric expansion coefficients were calculated from the density data.

To be able to accurately calculate the flow rate of the oil feed, the densities of the samples at high pressures were also measured. These measurements were performed using a DMA HPM density measurement cell (Anton Paar $\mathrm{GmbH}, \mathrm{Graz}$, Austria), which was calibrated with nitrogen and pure water. These densities were estimated to have an expanded uncertainty of $\pm 0.0004 \mathrm{~g} / \mathrm{cm}^{3}$ at the $95 \%$ level. The densities showed a linear dependence on temperature and pressure. Therefore, because the feed pump was always at room temperature, only a few data points at room temperature were needed for the hydrogen solubility calculations. For shale fuel oil the densities at $293.15 \mathrm{~K}$ were 1017.9 and 1022.9 
$\mathrm{kg} / \mathrm{m}^{3}$ at pressures of 1.52 and 99.29 bar, respectively. At $298.15 \mathrm{~K}$ the densities were 1014.7 and 1019.3 $\mathrm{kg} / \mathrm{m}^{3}$ at pressures of 10.22 and 99.62 bar. For the dephenolated shale fuel oil the densities at $293.15 \mathrm{~K}$ were 969.5 and $975.6 \mathrm{~kg} / \mathrm{m}^{3}$ at 5.18 and 119.22 bar. At $298.15 \mathrm{~K}$ and pressures of 5.1 and 119.19 bar the densities were 965.9 and $972.2 \mathrm{~kg} / \mathrm{m}^{3}$, respectively. A complete set of experimental density data, including data at higher temperatures, will soon be published as part of separate article that investigates the thermodynamic properties of these oil samples.

\subsubsection{Refractive index}

The refractive index at $589.592 \mathrm{~nm}$ was measured using an Abbemat HT refractometer (Anton Paar $\mathrm{GmbH}, \mathrm{Graz}$, Austria) and had a standard uncertainty of 0.0011 (expanded uncertainty of 0.0021 at the $95 \%$ level).

\subsubsection{Molecular weight}

The average molecular weight was measured using vapor pressure osmometry (Knauer K-7000,

Wissenschaftliche Gerätebau Dr. Ing. Herbert KNAUER GmbH, Germany), which had a standard uncertainty of $7 \mathrm{~g} / \mathrm{mol}$ (expanded uncertainty of $14 \mathrm{~g} / \mathrm{mol}$ at the $95 \%$ level).

\subsubsection{Infrared spectra and chemical composition}

Infrared spectra were measured using an Interspec 301-X portable mid-infrared spectrometer (Interspectrum OÜ, Tõravere, Estonia). The hydroxyl group content of the oils was determined from the infrared spectra using a model created with support vector regression. More details about the creation of these models is given in our earlier articles ${ }^{71,77}$. The model had a root mean squared error (RMSE) of $0.35 \mathrm{wt} \%$. These values for the hydroxyl group content were then used to calculate the number of hydroxyl groups per average molecule by multiplying by the average molecular weight of the sample and dividing by the molecular weight of a hydroxyl group.

Hydrogen and carbon content were also calculated from infrared spectra. Support vector regression was used to create the model for doing so, and was performed using experimental data for the hydrogen and carbon content of over 250 shale oil fractions. The RMSEs of these models were 0.133 wt\% for hydrogen and $0.564 \mathrm{wt} \%$ for carbon. The process for creating these models was similar to that used for creating a model for density in our earlier paper ${ }^{77}$. These values for the hydrogen and carbon content were then used to calculate the $\mathrm{H} / \mathrm{C}$ ratios given in Table 1.

\subsection{Measurements with the continuous flow apparatus}

The hydrogen solubility of the samples was measured using the continuous flow apparatus described by Saajanlehto ${ }^{78}$. The heart of this device is an optical cell in which the formation of a gaseous phase in the liquid sample can be observed using a video camera. This cell is maintained at a constant temperature and pressure. The sample and hydrogen gas are continuously fed into the cell. The flow rate of hydrogen gas is controlled using a mass flow controller (F230MI-AAD-11-V, Bronkhorst High-Tech, Ruurlo, Netherlands), and the liquid sample is fed using a syringe pump (Teledyne ISCO 260D, Teledyne ISCO, Lincoln, NE, USA). These flow rates determine the composition. The sample and hydrogen streams are combined in a T-joint, and then the mixture flows through a 3 meter long capillary tube to ensure complete mixing before it enters the optical cell.

Temperature was measured using a calibrated K-type thermocouple (Nokeval Oy, Nokia, Finland) that was placed in the metal housing of the optical cell. The temperature of the feed pump was also measured using one of these thermocouples. Pressure was measured using a Trafag pressure sensor (type 8253.74.2317, Trafag AG, Bubikon, Switzerland). The pressure in the system is maintained using a second syringe pump (Teledyne ISCO 500D, Teledyne ISCO, Lincoln, NE, USA), which also serves to collect the spent sample. Note that the third syringe pump shown in the original scheme of the apparatus ${ }^{78}$ (designated as "measurement pump") was not used. Hydrogen was obtained from AGA (Oy AGA Ab, Espoo, Finland) and was stated to have a purity of at least $99.995 \%$. 
The thermocouples and pressure sensor were calibrated immediately after measurements with the shale oil samples were completed. The thermocouples were calibrated against a Tempcontrol F200 thermometer (Tempcontrol Industrial Electronic Products B.V., Nootdorp, Netherlands) equipped with a Pt-100 RTD, which had been calibrated at the Finnish National Standards Laboratory (MIKES). The standard uncertainty of the thermocouples was estimated to be $0.06 \mathrm{~K}$ (expanded uncertainty of $0.13 \mathrm{~K}$ at the $95 \%$ level). The pressure sensor was calibrated using a Beamex MC2-PE calibrator with an EXT600 external pressure module, which had been calibrated by Beamex Oy Ab. Based on the calibration, the standard uncertainty of the Trafag pressure sensor was estimated to be 0.015 bar (expanded uncertainty of 0.034 bar at the $95 \%$ level). The mass flow controller was also calibrated to ensure the accuracy of the flow rate of hydrogen, and had a standard uncertainty of $0.30 \mathrm{mln} / \mathrm{min}$ (that is, normal milliliters per minute at the standard temperature and pressure of $1 \mathrm{~atm}$ and $273.15 \mathrm{~K}$ ) and an expanded uncertainty of $0.84 \mathrm{mln} / \mathrm{min}$.

Before beginning a measurement the sample was degassed by placing the bulb with the sample in an ultrasonic bath that contained ice water and using a vacuum pump to remove gases in the bulb. The sample was degassed for a minimum of 30 minutes. The sample was weighed before and after degassing, and on average $0.15 \mathrm{~g}(0.07 \%)$ of the sample was lost during degassing (the maximum amount lost was $0.3 \mathrm{~g}$, or $0.18 \%$ ). The feed pump was also connected to a vacuum pump to remove any gases and remaining solvents. Then the degassed sample was fed into the evacuated feed pump. Feeding the sample into the pump took a long time (about 1 hour for the dephenolated fuel oil and 3 to 7 hours for the fuel oil) because small capillary tubing is used in the continuous flow apparatus and the shale oil samples were fairly viscous (we estimate that the viscosity at room temperature was about $1000 \mathrm{mPa} \cdot \mathrm{s}$ for the shale fuel oil and about $20 \mathrm{mPa} \cdot \mathrm{s}$ for the dephenolated sample). To enable the sample to be fed in a reasonable timeframe, the sample was heated using a hair dryer or hot air gun. Safety was ensured during heating by keeping the temperature low enough that the vapor pressure of the sample was still well below atmospheric pressure.

Once the sample was in the feed pump and the temperature in the optical cell had stabilized then the system was filled with the oil sample and pressurized to the desired pressure. Low oil and hydrogen flow rates were then set to allow the system to stabilize, and then the flow rates were set to get the first composition to be measured. When measuring at a given composition, the system was allowed to stabilize for at least the residence time of the sample at the given flow rate and usually longer. The volume of the cell and the capillary tubes before the cell was approximately $5 \mathrm{ml}$ and oil flow rates of 0.4 to $1.4 \mathrm{ml} / \mathrm{min}$ were used. Once the system had stabilized the optical cell was observed for several minutes, using the video camera, to determine whether or not the mixture was in the 2-phase region. This procedure was repeated at different compositions to find the saturation composition, or the highest hydrogen concentration at which a single liquid phase still exists. The solubility limit at the given conditions is taken to be the average of the two compositions closest to the saturation composition; in other words, the average of the highest hydrogen concentration where a liquid phase is observed and the lowest hydrogen concentration where two phases are observed. Then, if there was still enough sample in the feed pump, the pressure or temperature was changed and measurements were performed at the new conditions.

The hydrogen solubility was calculated from the experimental data using Equation 1

$$
S=\frac{\dot{V}_{H 2}}{\dot{V}_{\text {oil }} \rho_{\text {oil }} \widehat{V}_{H 2}} \cdot 1000
$$

where $\mathrm{S}$ is the hydrogen solubility ( $\mathrm{mol} \mathrm{H} / \mathrm{kg}$ oil), $\dot{V}_{\mathrm{H} 2}$ is the volumetric flow rate of hydrogen ( $\mathrm{mln} / \mathrm{min}$, normal milliliters per minute) at standard conditions ( $1 \mathrm{~atm}$ and $273.15 \mathrm{~K}$ ), $\dot{V}_{\text {oil }}$ is the volumetric flow rate of the oil sample, $\rho_{\text {oil }}$ is the density of the oil at the temperature and pressure in the feed pump 
during the experiment and $\widehat{V}_{\mathrm{H} 2}$ is the molar volume of hydrogen at standard temperature and pressure ( $1 \mathrm{~atm}$ and $273.15 \mathrm{~K}$ ). The molar volume of hydrogen was taken from the NIST webbook ${ }^{79}$ and was 22250 $\mathrm{ml} / \mathrm{mol}$.

\subsection{Reactions during the study}

Some problems arose during the experiments that seem to be caused by reactions that occurred with the shale oil. This was first noticed when particles formed in the fuel oil sample at $573 \mathrm{~K}$. The oven was heated to $573 \mathrm{~K}$ to prepare for experiments at that temperature, and fuel oil from the previous run was still in the system. The oven was at this temperature for about 6 hours while a new portion of fuel oil was loaded into the feed pump. When the camera was turned on to begin the experiment then it was observed that the optical cell contained some sort of heavy residue. As the new fuel oil was fed through the system this residue was broken up into particles. The long time period spent at a high temperature and pressure seems to have caused the shale fuel oil to react.

Particle formation was observed only once at the short residence times used during actual experiments. This occurred with the dephenolated oil at $527.2 \mathrm{~K}$ and 139.71 bar. This run had the lowest oil flow rate of any of the experiments $(0.4 \mathrm{ml} / \mathrm{min})$, which means the oil also had the longest residence time in the hot zone (about $13 \mathrm{~min}$ ). For comparison, the average residence time for all the measurements was $6 \mathrm{~min}$. A picture of these particles is given in Figure 3. This data point still had a hydrogen solubility value that lined up with the remaining data for the dephenolated sample, and it was not removed. However, it should be noted that changes in the composition may have been large enough to affect the hydrogen solubility for that data point. At the same temperature and lower pressures (and also higher flow rates) particle formation was not observed. The residence times for these runs were 8 $\min$ and 3 min.
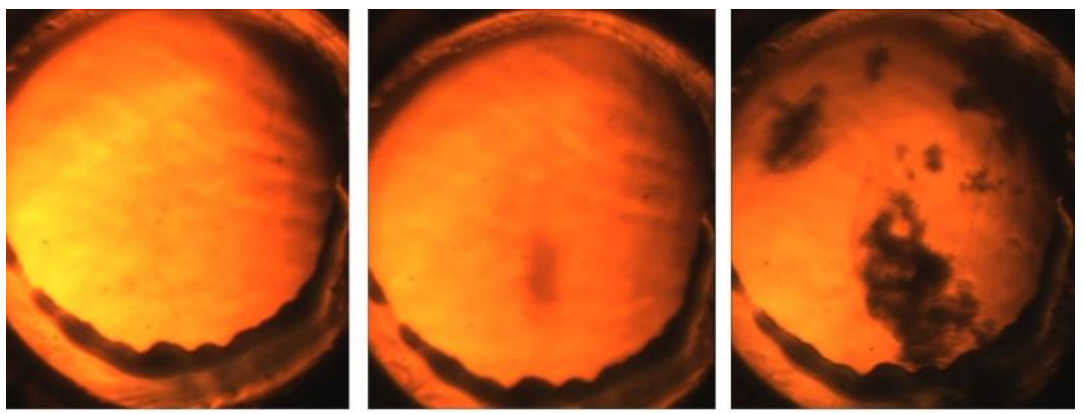

Figure 3. Pictures from the experiments. Left: the liquid phase; center: a small bubble flowing through the optical cell; right: particles formed when measuring dephenolated shale fuel oil at $527.2 \mathrm{~K}$ and 139.71 bar.

\subsection{Uncertainty analysis}

The uncertainty in the measured solubility values was assessed using a Monte Carlo method (see ISO/IEC Guide $98-3^{80}$ ). This involved specifying a probability distribution for each parameter that could affect the uncertainty of the measurements, randomly sampling these distributions and then using each set of sampled values to calculate a solubility. A distribution of solubility values was then obtained; the variance of this distribution was taken to be the standard uncertainty of the measured value. The expanded uncertainty at the $95 \%$ level was also calculated from the probability density function. 9 parameters were varied in the Monte Carlo simulation, and the statistical sample size used with this method was 100,000 . In addition to the uncertainties of the parameters used in Equation 1, the uncertainty in the measured temperature and pressure of the cell were also included in the error model 
by multiplying the deviation of these values from the mean by the sensitivity of the hydrogen solubility to the temperature and the pressure. The sensitivity was calculated as the partial derivative of the hydrogen solubility with respect to temperature or pressure at the measurement conditions.

The accuracy of the measurements was also checked by measuring the hydrogen solubility of toluene. The toluene used was obtained from Merck and had a purity of $\geq 99.9 \%$ (as measured by the producer using gas chromatography). The measured value is shown in Table 2 along with literature values at approximately the same conditions measured by Saajanlehto et al. ${ }^{78}$ and Simnick et al. ${ }^{81}$. This analysis confirms that the experimental procedure gave accurate values, with uncertainties at a level that is commonly expected for hydrogen solubility measurements.

Table 2. Measured and literature values for the mole fraction of hydrogen that is soluble in toluene $\left(x_{H 2}\right)$.

\begin{tabular}{c|ccc}
\hline Source & Temperature (K) & Pressure (bar) & $\mathbf{X}_{\mathbf{H 2}}$ \\
\hline this work & 505.6 & 49.72 & $0.038 \pm 0.0027$ \\
Saajanlehto et al. $^{78}$ & 501.6 & 50.0 & 0.037 \\
Saajanlehto et al. $^{78}$ & 502.0 & 49.9 & 0.037 \\
Simnick et al. ${ }^{81}$ & 502.2 & 50.7 & 0.0375 \\
\hline
\end{tabular}

\section{Results and Discussion}

\subsection{Measured data}

In total, 15 data points were measured for the shale oil samples from 424 to $527 \mathrm{~K}$ and from 40 to 140 bar. This data is presented in Table 3. The data is also presented graphically in Figure 4 and Figure 5. The solubility of hydrogen in the oil samples increases with pressure and temperature, as would be expected $^{3}$. The dephenolated sample had a hydrogen solubility that was about $0.1 \mathrm{~mol} \mathrm{H}_{2} / \mathrm{kg}$ oil higher than the shale fuel oil, which is an increase of about 15 to $45 \%$, depending on the hydrogen solubility. This increase is reasonable given that oxygenated pure compounds generally have lower solubilities than comparable hydrocarbons that do not contain oxygen ${ }^{3}$. As shown in Table 1, the average molecule in the shale fuel oil contains 0.75 hydroxyl groups, which means that roughly 3 out of 4 molecules contain a hydroxyl group. For the dephenolated shale fuel oil only 1 in 6 molecules contain a hydroxyl group, which is a significant decrease. In addition to the difference in hydroxyl group content, it is likely that the aromatic structure in the phenols also decreases the hydrogen solubility. Therefore, the increase in hydrogen solubility for the dephenolated sample is probably also related to the decrease in aromatic rings that occurs when removing the phenolic compounds.

Table 3. Measured values for the hydrogen solubility $\left(\mathrm{S}_{\mathrm{H} 2}\right)$ and mole fraction of hydrogen in the liquid phase $\left(x_{\mathrm{H} 2}\right)$ for the shale oil samples. $\left.\mathrm{u}_{(}\right)$denotes the expanded uncertainty at the $95 \%$ level.

\section{Shale fuel oil}

\begin{tabular}{cccccc} 
Temperature & Pressure & $\mathbf{S}_{\mathbf{H} 2}$ & $\mathbf{u}\left(\mathbf{S}_{\mathbf{H} 2}\right)$ & $\mathbf{X}_{\mathbf{H} 2}$ & $\mathbf{u}\left(\mathbf{X}_{\mathbf{H} 2}\right)$ \\
\hline$K$ & bar & $\mathrm{mol} \mathrm{H}_{2} / \mathrm{kg}$ oil & $\mathrm{mol} \mathrm{H}_{2} / \mathrm{kg}$ oil & & \\
\hline 527.1 & 119.92 & 0.47 & \pm 0.034 & 0.103 & \pm 0.0084 \\
475.9 & 139.93 & 0.45 & \pm 0.025 & 0.098 & \pm 0.0070 \\
475.9 & 100.01 & 0.32 & \pm 0.029 & 0.072 & \pm 0.0072 \\
475.9 & 60.11 & 0.18 & \pm 0.020 & 0.041 & \pm 0.0051 \\
423.9 & 139.97 & 0.32 & \pm 0.019 & 0.073 & \pm 0.0055 \\
423.9 & 80.12 & 0.17 & \pm 0.019 & 0.040 & \pm 0.0048 \\
527.1 & 80.07 & 0.31 & \pm 0.029 & 0.070 & \pm 0.0072
\end{tabular}




\begin{tabular}{cccccc}
501.5 & 139.91 & 0.51 & \pm 0.038 & 0.109 & \pm 0.0091 \\
501.6 & 100.02 & 0.35 & \pm 0.033 & 0.078 & \pm 0.0079 \\
501.6 & 60.16 & 0.19 & \pm 0.020 & 0.044 & \pm 0.0051 \\
\hline \multicolumn{7}{c}{ Dephenolated shale fuel oil } \\
Temperature & Pressure & $\mathbf{S}_{\mathrm{H} 2}$ & $\mathbf{u}\left(\mathbf{S}_{\mathbf{H} 2}\right)$ & $\mathbf{X}_{\mathbf{H} 2}$ & $\mathbf{u}\left(\mathbf{x}_{\mathbf{H} 2}\right)$ \\
\hline$K$ & bar & $\mathrm{mol} \mathrm{H}_{2} / \mathrm{kg}$ oil & $\mathrm{mol} \mathrm{H}_{2} / \mathrm{kg}$ oil \\
\hline 423.9 & 139.72 & 0.45 & \pm 0.031 & 0.102 & \pm 0.0080 \\
423.9 & 79.86 & 0.25 & \pm 0.028 & 0.058 & \pm 0.0069 \\
527.2 & 139.71 & 0.68 & \pm 0.069 & 0.145 & \pm 0.0144 \\
527.2 & 99.85 & 0.45 & \pm 0.046 & 0.102 & \pm 0.0106 \\
527.2 & 39.86 & 0.13 & \pm 0.018 & 0.032 & \pm 0.0045 \\
\hline
\end{tabular}




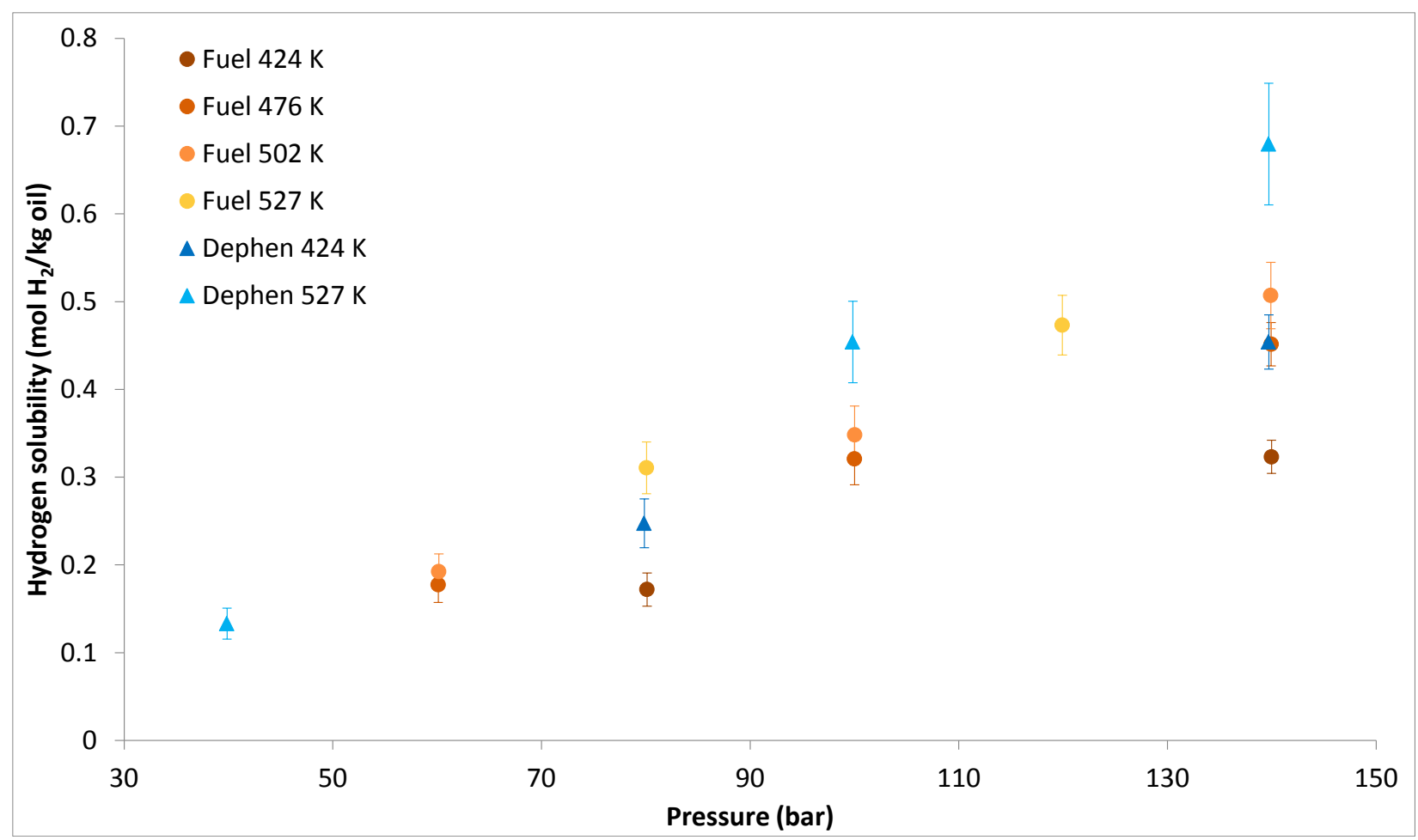

Figure 4. Measured hydrogen solubilities for the shale fuel oil and dephenolated shale fuel oil.

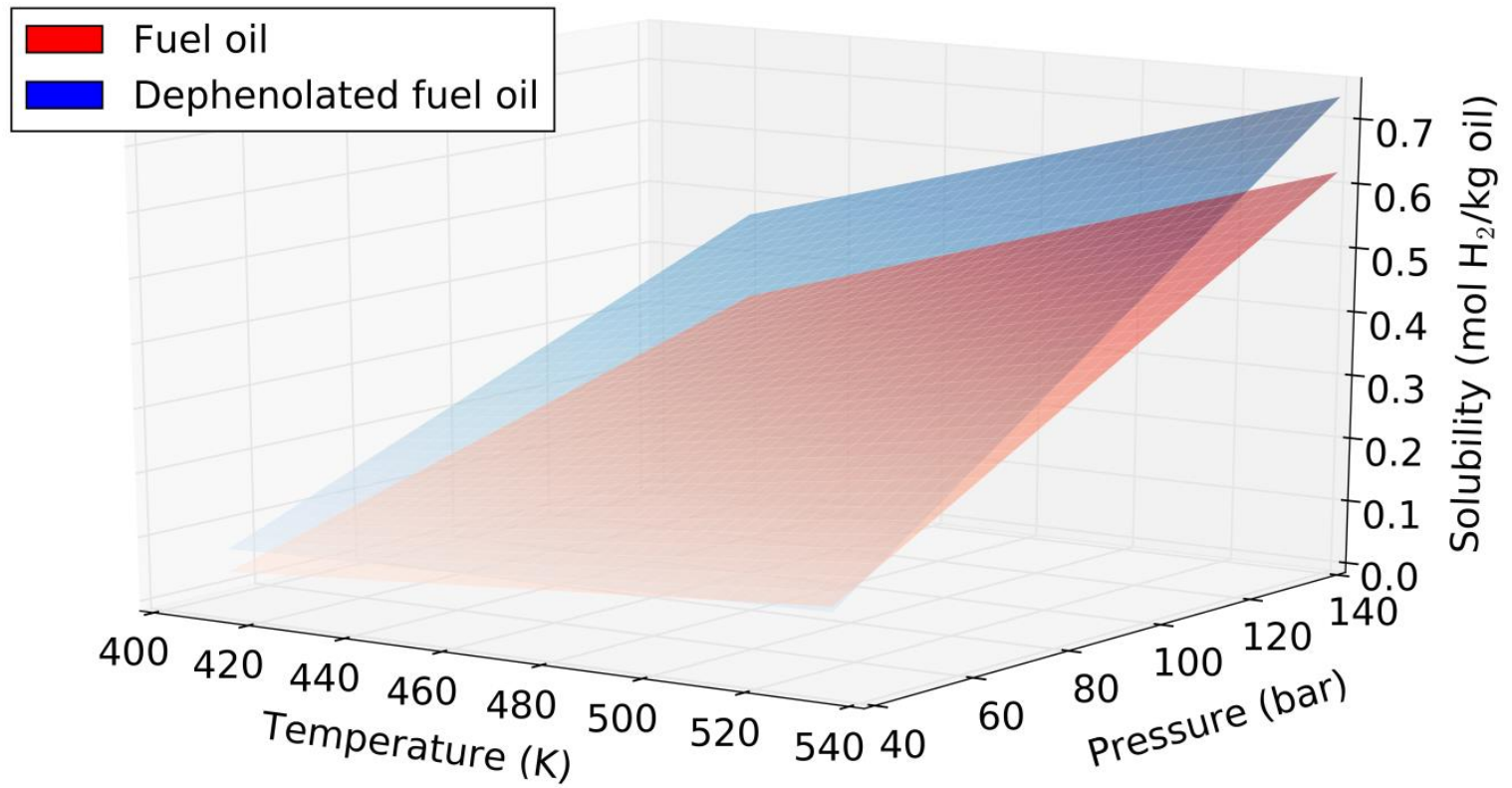

Figure 5. Measured hydrogen solubilities of the shale oil samples.

By comparing the measured data to data found in the literature (available at https://osf.io/dhkew/), it can be seen that the shale fuel oil has a relatively low hydrogen solubility. This is illustrated in Figure 6, which compares the literature data and the shale oil samples. The hydrogen solubility of the shale fuel oil sample falls below almost all of the other fuel samples. Two of the main molecular structures in shale oil produced from Kukersite oil shale, such as the samples in this study, are aromatic rings and functional groups containing oxygen. In general, compounds with these structures have lower hydrogen solubilities than $n$-alkanes, as seen from general trends in data for pure 
compounds $^{3}$ (see Figure 7). For example, benzene has a lower hydrogen solubility than hexane, as does hexanol. The Kukersite shale oil samples match most closely with compounds that have aromatic rings, such as $\mathrm{m}$-cresol, eugenol and methylnaphthalene. Therefore, it is reasonable to expect that Kukersite shale oil would have a relatively low hydrogen solubility. In support of this reasoning, the dephenolated fuel oil has a higher hydrogen solubility that is similar to many of the other fuel samples, which indicates that the phenolic compounds present in Kukersite shale oil decrease the hydrogen solubility. Interestingly, the bio oil samples also have a higher solubility than the shale fuel oil. The bio oils were cottonseed, jojoba and tall oils, and they consisted mainly of acids and esters with long straight chain alkenes that had one or two double bonds ${ }^{47,48,50}$. The added aromatic rings in the phenols of the shale oil are likely the reason for its lower hydrogen solubility. The dephenolated shale oil had a hydrogen solubility that was more comparable to those bio oils. 

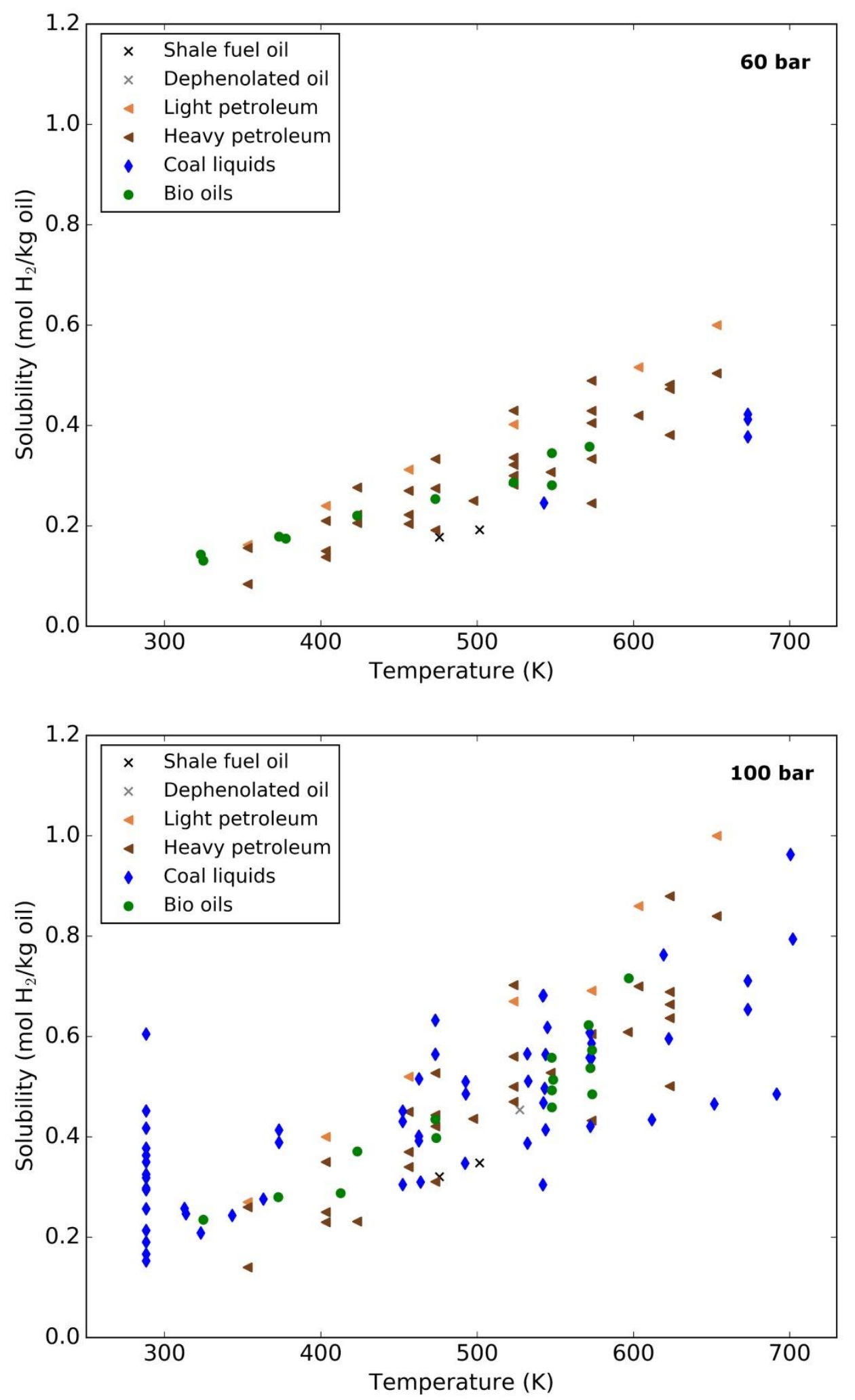

Figure 6. A comparison of the hydrogen solubilities of the shale oil samples and other oils at approximately 60 and 100 bar (data at https://osf.io/dhkew/). 


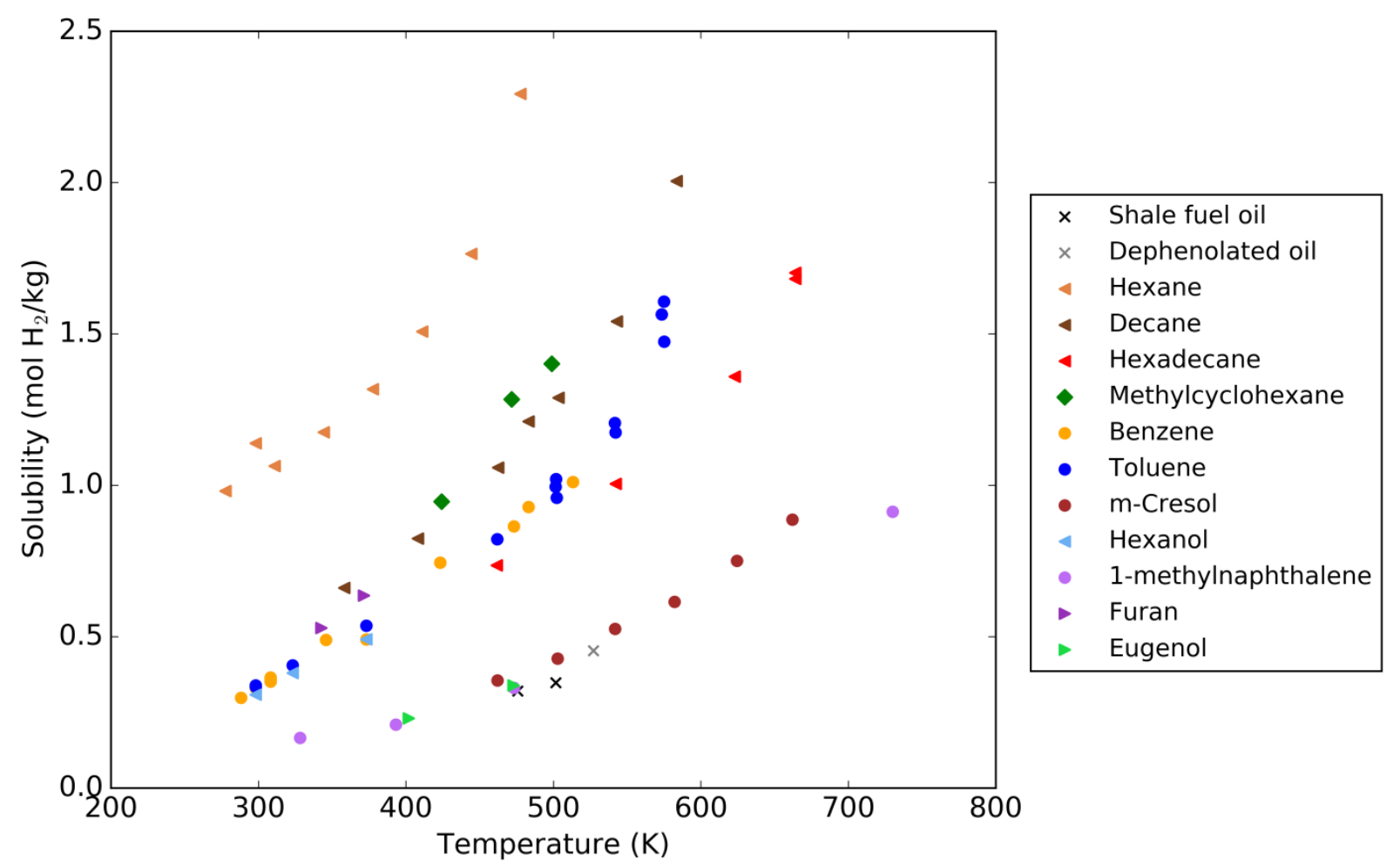

Figure 7. Comparison of the hydrogen solubilities of selected pure compounds at about 100 bar. Data taken from Young ${ }^{3}$ and Qureshi et al. ${ }^{6}$.

\subsection{Modeling hydrogen solubility in Kukersite shale oil}

Hydrogen solubility is generally modelled and predicted using equations of state; however, this requires the equation of state parameters to be predicted or fit to experimental data. Because there is no method for predicting these parameters for Kukersite shale oil that is known to be reliable and experimental data necessary for fitting was not available, an equation of state was not used for modeling the hydrogen solubility. Instead, the method presented by Riazi and Roomi ${ }^{82}$ was used. This method only requires the average molecular weight of the fuel and a rough estimate of the composition.

The core of this method is the vapor liquid equilibria relationship given as Equation 4 in the reference $^{82}$ (shown here as Equation 2).

$$
x_{1}=\frac{\phi_{1}^{V} P_{1}}{\gamma_{1} f_{1}^{L}}
$$

where $x_{1}$ is the mole fraction of component 1 (in this case hydrogen) in the liquid phase, $\phi_{1}{ }^{v}$ is the fugacity coefficient of component 1 in the gas phase, $P_{1}$ is the partial pressure, $\gamma_{1}$ is the activity coefficient in the solvent liquid phase, and $f_{1}{ }^{L}$ is the fugacity of component 1 as a pure liquid at the given pressure and temperature. For light gases like hydrogen $f_{1}{ }^{L}$ is taken to be the fugacity of a hypothetical liquid.

The activity coefficient $\gamma_{1}$ is estimated using Scatchard-Hildebrand theory, and the solubility parameter and molar volume of the fuel needed for this calculation are predicted from correlations given in the reference ${ }^{82}$ that are based on model pure compounds. The liquid phase fugacity $f_{1}{ }^{L}$ is estimated using Equation 8 in the reference ${ }^{82}$ (shown here as Equation 3) 


$$
f_{1}^{L}=f_{r}^{\circ L} P_{C} \exp \left[\frac{V_{1}^{L}(P-1.013)}{R T}\right]
$$

where $f_{r}^{\circ L}$ is the reduced hypothetical liquid fugacity at $1 \mathrm{~atm}, P_{c}$ is the critical pressure of component 1 , $V_{1}{ }^{L}$ is the molar volume, $P$ is the pressure, $R$ is the ideal gas constant and $T$ is the temperature. Riazi and Roomi treat $f_{r}^{\circ L}$ as an adjustable parameter to enable a better fit. They also introduce a second adjustable parameter $\alpha$ which functions as a correction factor for the hypothetical solubility parameter and molar volume of liquid hydrogen at $298 \mathrm{~K}$. These two parameters are chosen depending on the composition of the solvent or fuel.

When using this method for the shale oil samples the solubility parameter was estimated using only the correlation for alkylbenzenes (Equation 22 in the reference ${ }^{82}$ ), and the molar volumes were calculated directly from the measured molecular weights and densities. Riazi and Roomi suggest that for aromatic fuels the parameters $\alpha$ and $f_{r}{ }^{\circ}$ be set to 1.27 and 30, respectively, and these suggested values were used first. When using these parameters a poor fit was obtained: for the shale fuel oil the RMSE of the mole fraction was 0.080 (an average relative deviation, \%AAD, of $111 \%$ ) and for the dephenolated fuel oil the RMSE was 0.062 (\%AAD of 74\%). Figure 8 shows the predicted values graphically. The method, as is, significantly over predicts the hydrogen solubility.

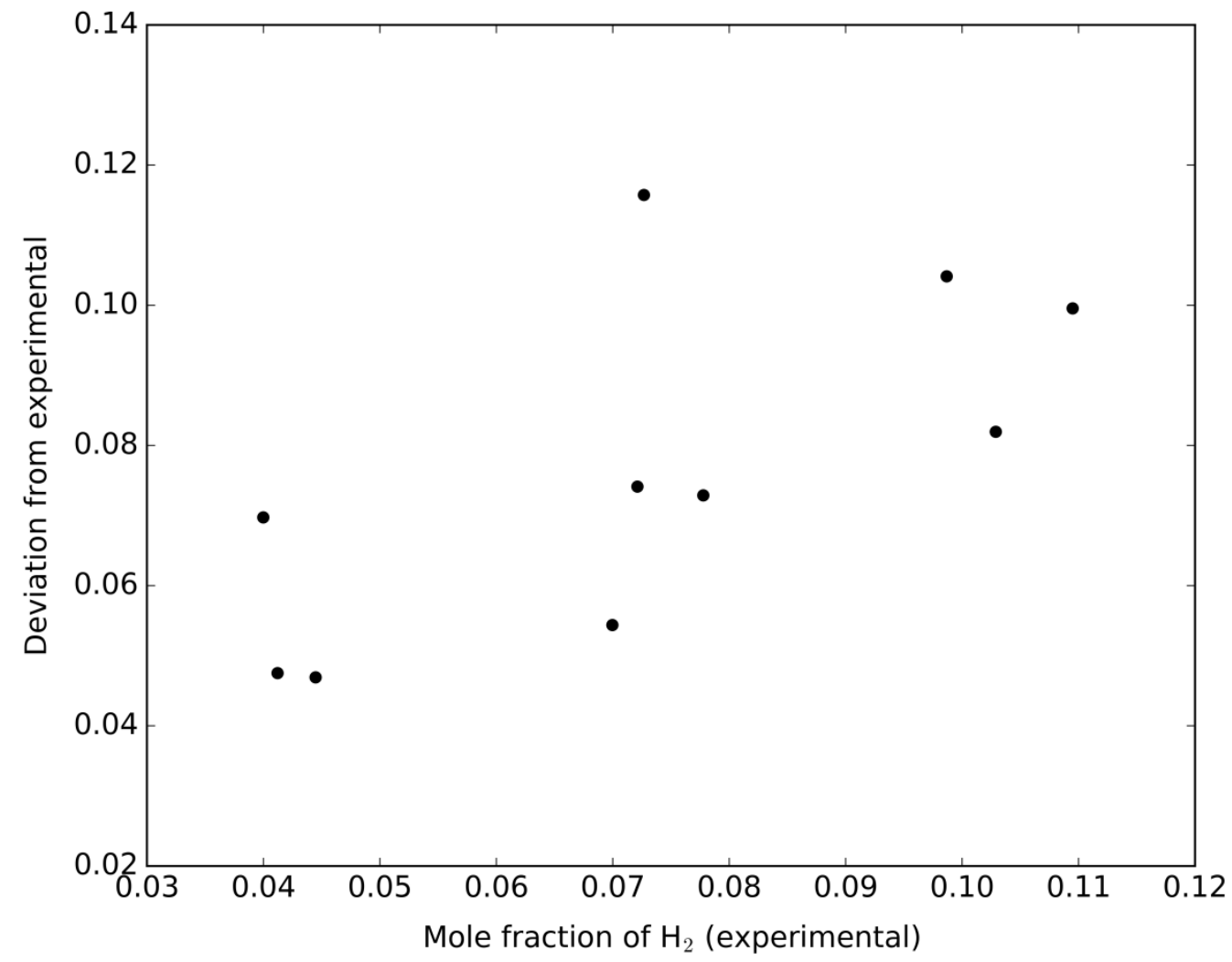

Figure 8. A comparison of the hydrogen solubility predicted using the method given by Riazi and Roomi ${ }^{82}$ and the experimental data for the shale fuel oil sample. Deviation calculated as predicted minus experimental.

The immediate question is whether or not the method can be modified to provide a good fit for the shale oil samples. This method takes composition into account in two places: in calculation of the solubility parameter of the fuel and in choosing the values for $\alpha$ and $f_{r}{ }^{\circ}$. Based on data and estimates for pure alkylphenols ${ }^{83}$ it seems that the solubility parameter should be close to that of alkylbenzenes, so 
the solubility parameter was left unchanged. Therefore, it seems likely that $\alpha$ and $f_{r}{ }^{\circ L}$ would need to be optimized for use with Kukersite shale oil samples. Directly optimizing these parameters does give a good fit, with an RMSE at about the level of the experimental uncertainty (RMSE of the mole fraction of 0.0016; \%AAD of 2.1\%). However, it seems unlikely that these parameters could be inferred from compositional trends identified for other fuels by Riazi and Roomi ${ }^{82}$, especially because both values are significantly lower than any values used for other solvents or fuels (optimal values were -0.045 and 12.5 for $\alpha$ and $f_{r}{ }^{\circ}$ ). Also, these shale fuel oil parameters do not provide a good fit for the dephenolated sample, for which the optimal values were 0.42 and 20 (also lower than expected). Therefore, it seems doubtful that these optimized values would provide good predictions for other Kukersite shale oil products, and data for more samples would be needed to take compositional differences into account.

When analyzing the solution space of the Riazi and Roomi method it was seen that the accuracy of the fit was quite sensitive to changes in alpha, at least for the experimental data presented here. Deviations from the optimal value of more than 0.05 quickly resulted in a \%AAD of more than $10 \%$. This also makes it seem unlikely that the parameters for this shale fuel oil sample would give good results when used for other shale oil samples.

For modeling, a more accurate approach for shale oil samples like these could be to estimate parameters for an equation of state by using the pseudocomponent approach, where the fuel is represented as a mixture of a small number of compound classes whose values can be predicted from data for pure compounds ${ }^{84}$. Future modeling studies could take this approach, but to do so more detailed information would be needed about the samples, such as a distillation curve and density data for the distilled fractions. Also, the main class of compound in this shale oil, alkylphenols, is not found in petroleum, and new correlations would have to be developed for predicting the properties of alkylphenolic pseudocomponents. Likely this would require more experimental data to be measured for pure alkylphenols.

\section{Conclusions}

Experimental data presented here shows that Kukersite shale oil has a hydrogen solubility that is lower than most other fuels, which is most likely due to the high amount of polar aromatic compounds (phenolic compounds) in the oil. Some of these phenolic compounds were removed from the oil using extraction, and the hydrogen solubility of this dephenolated oil was noticeably higher. Signs of chemical reactions were also observed when the oil had a longer residence time in the hot zone, and thus, maintaining low residence times seems to be important for obtaining trustworthy measurements for these oils.

It seems probable that the data for the shale fuel oil also gives a good indication of the solubility behavior of the heavy shale oil because they have similar molecular structures (see Figure 2 ). In the future it would be useful confirm this assumption by performing experiments with the heavy shale oil.

Prediction methods developed for petroleum and coal liquid fuels cannot currently be used for predicting the solubility of Kukersite shale oil. More accurate predictions could be obtained if additional measurements were made for other shale oil samples or if methods were developed for predicting equation of state parameters for shale oil.

\section{Acknowledgements}

Part of the funding for this research came from a grant awarded by the European Regional Development Fund under the Dora Plus Program. The authors also thank Jouni Touronen for his help with the continuous flow apparatus and Sven Kamenev for building the liquid-liquid extraction device. 


\section{References}

(1) Letcher, T. M. Development and Applications in Solubility; Royal Society of Chemistry, 2007.

(2) Stratiev, D.; Tzingov, T.; Shishkova, I.; Dermatova, P. Hydrotreating Units Chemical Hydrogen Consumption Analysis a Tool for Improving Refinery Hydrogen Management. In Proc. 44th International Petroleum Conference; Bratislava, Slovak Republic, 2009.

(3) Young, C. L. IUPAC Solubility Data Series; Pergamon Press: Oxford, UK, 1981; Vol. 5/6.

(4) Kruyer, S.; Nobel, A. P. P. Solubility of Hydrogen in Benzene, Cyclohexane, Decalin, Phenol and Cyclohexanol. Recl. Trav. Chim. Pays-Bas 1961, 80 (10), 1145-1156 DOI: 10.1002/recl.19610801011.

(5) Simnick, J. J.; Sebastian, H. M.; Lin, H. M.; Chao, K. C. Gas-Liquid Equilibrium in Mixtures of Hydrogen + M-Xylene and + M-Cresol. The Journal of Chemical Thermodynamics 1979, 11 (6), 531-537 DOI: 10.1016/0021-9614(79)90091-0.

(6) Qureshi, M. S.; Touronen, J.; Uusi-Kyyny, P.; Richon, D.; Alopaeus, V. Solubility of Hydrogen in BioOil Compounds. The Journal of Chemical Thermodynamics 2016, 102, 406-412 DOI: 10.1016/j.jct.2016.07.010.

(7) Just, G. Zeitschrift für Physikalische Chemie 1901, 37, 342-367.

(8) Katayama, T.; Nitta, T. Solubilities of Hydrogen and Nitrogen in Alcohols and N-Hexane. J. Chem. Eng. Data 1976, 21 (2), 194-196 DOI: 10.1021/je60069a018.

(9) Makranczy, J.; Rusz, L.; Balog-Megyery, K. Hungarian Journal of Industrial Chemistry 1979, 7, 4146.

(10) Carius, L. Justus Liebigs Annalen Der Chemie 1855, 94, 129-166.

(11) Maxted, E. B.; Moon, C. H. The Temperature Coefficient of the Solubility of Hydrogen in Organic Solvents. Trans. Faraday Soc. 1936, 32 (0), 769-775 DOI: 10.1039/TF9363200769.

(12) Cargill, R. W. Solubility of Helium and Hydrogen in Some Water + Alcohol Systems. J. Chem. Soc., Faraday Trans. 1 1978, 74 (0), 1444-1456 DOI: 10.1039/F19787401444.

(13) Ijams, C. C. Ph.D. Thesis, Vanderbilt University: Nashville, TN, USA, 1941.

(14) Cauquil, G. J. Chim. Phys. 1927, 24, 53-55.

(15) Puri, P. S.; Ruether, J. A. Additive Excess Free Energy Models for Predicting Gas Solubilities in Mixed Solvents. Can. J. Chem. Eng. 1974, 52 (5), 636-640 DOI: 10.1002/cjce.5450520515.

(16) Frolich, P. K.; Tauch, E. J.; Hogan, J. J.; Peer, A. A. Solubilities of Gases in Liquids at High Pressure. Ind. Eng. Chem. 1931, 23 (5), 548-550 DOI: 10.1021/ie50257a019.

(17) Krichevskii, I. R.; Zhavoronokov, N. M.; Tsiklis, T. S. Zh. Fiz. Khim. 1937, 9, 317-328.

(18) Krichevskii, I. R.; Efremova, G. D. Zh. Fiz. Khim. 1951, 25, 577-583.

(19) Michels, A.; de Graaff, W.; van der Somme, J. Appl. Sci. Res. 1953, A4, 105-108.

(20) Yorizane, M.; Sadamoto, S.; Masuoka, H.; Eto, Y. Kogyo Kagaku Zasshi 1969, 72, 2174-2177.

(21) Brunner, E. Solubility of Hydrogen in Diols and Their Ethers. The Journal of Chemical Thermodynamics 1980, 12 (10), 993-1002 DOI: 10.1016/0021-9614(80)90140-8.

(22) Brunner, E. Ber Bunsenges. Phys. Chem. 1979, 83, 715.

(23) Jaatinen, S.; Touronen, J.; Karinen, R.; Uusi-Kyyny, P.; Alopaeus, V. Hydrogen Solubility in Furfural and 2-Propanol: Experiments and Modeling. The Journal of Chemical Thermodynamics 2017, 112, 1-6 DOI: 10.1016/j.jct.2017.04.004.

(24) Androsov, D. I.; Loktev, S. M. Zh. Fiz. Khim. 1978, 52, 1348.

(25) Tyvina, T. N.; Valuev, K. I.; Vasileva, I. I.; Sokolov, B. I.; Kharchenko, A. A. Zhur. Prikl. Khim. 1977, $50,2578$.

(26) Schröder, W. Beobachtungen an Lösungen von Gasen in Flüssigkeiten. Zeitschrift für Naturforschung 1969, 24B, 500.

(27) Krauss, W.; Gestrich, W. Chem. - Tech. (Heidelberg) 1977, 6, 35-37.

(28) Horiuti, J. Sai. pap. Inst. Phys. Chern. Res. 1931, 17, 125-256. 
(29) Guerry, D. J. Ph.D. Thesis, Vanderbilt University: Nashville, TN, USA, 1944.

(30) Schmack, P.; Bittrich, H.-J. Wiss. Z. Tech. Hochsch. Chem. Leuna- Merseburg 1966, 8 (2-3), 182186.

(31) Shakhova, S. F.; Zubchenko, Y. P.; Kaplan, L. K. Khim. Prom. 1973, 49, 108-110.

(32) Cai, H.-Y.; Shaw, J. M.; Chung, K. H. Hydrogen Solubility Measurements in Heavy Oil and Bitumen Cuts. Fuel 2001, 80 (8), 1055-1063 DOI: 10.1016/S0016-2361(00)00171-X.

(33) Ji, S.; Wang, Z.; Guo, A.; Zhou, Y.; Chen, K. Determination of Hydrogen Solubility in Heavy Fractions of Crude Oils by a Modified Direct Method. J. Chem. Eng. Data 2013, 58 (12), 3453-3457 DOI: 10.1021/je400729v.

(34) Lal, D.; Otto, F. D.; Mather, A. E. Solubility of Hydrogen in Athabasca Bitumen. Fuel 1999, 78 (12), 1437-1441 DOI: 10.1016/S0016-2361(99)00071-X.

(35) Saajanlehto, M.; Uusi-Kyyny, P.; Alopaeus, V. Hydrogen Solubility in Heavy Oil Systems: Experiments and Modeling. Fuel 2014, 137, 393-404 DOI: 10.1016/j.fuel.2014.08.015.

(36) Ronze, D.; Fongarland, P.; Pitault, I.; Forissier, M. Hydrogen Solubility in Straight Run Gasoil. Chemical Engineering Science 2002, 57 (4), 547-553 DOI: 10.1016/S0009-2509(01)00404-3.

(37) Fahim, M. A.; Elkilani, A. S. Prediction of the Solubility of Hydrogen in Naphtha Reformate Using the Modified UNIFAC Group Contribution Method. Ind. Eng. Chem. Res. 1991, 30 (1), 255-259 DOI: 10.1021/ie00049a039.

(38) Hadden, S. T. Vapor-Liquid Equilibria in Hydrocarbon Systems. Chemical Engineering Progress 1948, 44 (1), 37-54.

(39) Lin, H.-M.; Sebastian, H. M.; Simnick, J. J.; Chao, K.-C. Solubilities of Hydrogen and Methane in Coal Liquids. Ind. Eng. Chem. Proc. Des. Dev. 1981, 20 (2), 253-256 DOI: 10.1021/i200013a012.

(40) Harrison, R. H.; Scheppele, S. E.; Sturm, G. P.; Grizzle, P. L. Solubility of Hydrogen in Well-Defined Coal Liquids. J. Chem. Eng. Data 1985, 30 (2), 183-189 DOI: 10.1021/je00040a016.

(41) Wiegand, K. W.; Strobel, B. O.; Hofmann, H. Vapour-Liquid Equilibria of Hydrogen/Coal Liquid and Methane/Coal Liquid Systems at Elevated Temperatures and Pressures. Chem. Eng. Technol. 1989, 12 (1), 280-288 DOI: 10.1002/ceat.270120139.

(42) Ding, F. X.; Chiang, S. H.; Klinzing, G. E. Hydrogen and Methane Solubility in SRC-II Coal Liquid. Prepr. Pap., Am. Chem. Soc., Div. Fuel Chem.; (United States) 1983, 28:5.

(43) Sung, S. Phase Equilibrium of the Hydrogen/Coal Liquid System; Pittsburgh Univ., PA (USA), 1981.

(44) Wiegand, K. W. Experimentelle Bestimmung Und Theoretische Beschreibung von Phasengleichgewichten Zwischen Kohleölen Und H2 Bzw. CH4; PhD dissertation; FriedrichAlexander-Universität: Erlangen-Nürnberg, 1986.

(45) Lin, H. M.; Leet, W. A.; Kim, H.; Chao, K. C. Measurement and Prediction of Vapor-Liquid Equilibrium for an H-Coal and an SRC Coal Liquid with and without Hydrogen. Ind. Eng. Chem. Proc. Des. Dev. 1985, 24 (4), 1225-1230 DOI: 10.1021/i200031a055.

(46) Prather, J. W.; Ahangar, A. M.; Pitts, W. S.; Henley, J. P.; Tarrer, A. R.; Guin, J. A. Solubility of Hydrogen in Creosote Oil at High Temperatures and Pressures. Ind. Eng. Chem. Proc. Des. Dev. 1977, 16 (3), 267-270 DOI: 10.1021/i260063a002.

(47) Wisniak, J.; Stein, S. Hydrogen Solubility in Jojoba Oil. J Am Oil Chem Soc 1974, 51 (11), 482-485 DOI: $10.1007 /$ BF02635856.

(48) Wisniak, J.; Albright, L. Hydrogenating Cottonseed Oil at Relatively High Pressure. Ind. Eng. Chem. 1961, 53 (5), 375-380 DOI: 10.1021/ie50617a025.

(49) Tomoto, N.; Kusano, K. The Solubility of Gases in Fatty Oils. Journal of Japan Oil Chemists' Society 1967, 16 (3), 108-113 DOI: 10.5650/jos1956.16.108.

(50) Uusi-Kyyny, P.; Pakkanen, M.; Linnekoski, J.; Alopaeus, V. Hydrogen Solubility Measurements of Analyzed Tall Oil Fractions and a Solubility Model. The Journal of Chemical Thermodynamics 2017, 105, 15-20 DOI: 10.1016/j.jct.2016.10.008. 
(51) Laugier, S.; Richon, D.; Renon, H. Vapour-Liquid Equilibria Hydrogen-White Oil up to $625.1 \mathrm{~K}$ and $35 \mathrm{MPa}$. Fuel 1983, 62 (7), 842-844 DOI: 10.1016/0016-2361(83)90039-X.

(52) Schofield, B. A.; Ring, Z. E.; Missen, R. W. Solubility of Hydrogen in a White Oil. Can. J. Chem. Eng. 1992, 70 (4), 822-824 DOI: 10.1002/cjce.5450700431.

(53) Lee, S. Oil Shale Technology; CRC Press, 1990.

(54) Oja, V.; Suuberg, E. M. Oil Shale Processing, Chemistry and Technology. In Fossil Energy; Malhotra, R., Ed.; Springer New York, 2013; pp 99-148.

(55) Zhang, X.-S.; Wang, H.-J.; Ma, F.; Sun, X.-C.; Zhang, Y.; Song, Z.-H. Classification and Characteristics of Tight Oil Plays. Pet. Sci. 2016, 13 (1), 18-33 DOI: 10.1007/s12182-015-0075-0.

(56) Urov, K.; Sumberg, A. Characteristics of Oil Shales and Shale-like Rocks of Known Deposits and Outcrops: Monograph; Oil shale Special; Estonian Acad. Publ: Tallinn, 1999.

(57) World Energy Council. World Energy Resources; World Energy Council: London, 2013.

(58) Luts, K. The Estonian Oil Shale Kukersite, its Chemistry, Technology and Analysis (Der estländische Brennschiefer-Kukersit, seine Chemie, Tehnologie und Analyse); K. Mattiesens Buchdruckerei Ant.Ges.: Tartu, Estonia, 1934.

(59) Yu, H.; Li, S.; Jin, G. HYDRODESULFURIZATION AND HYDRODENITROGENATION OF DIESEL DISTILLATE FROM FUSHUN SHALE OIL. Oil Shale 2010, 27 (2), 126 DOI: 10.3176/oil.2010.2.03.

(60) Holmes, S. A.; Thompson, L. F. Nitrogen Compound Distributions in Hydrotreated Shale Oil Products from Commercial-Scale Refining. Fuel 1983, 62 (6), 709-717 DOI: 10.1016/00162361(83)90312-5.

(61) Thompson, L. F.; Holmes, S. A. Effect of Multistage Hydroprocessing on Aromatic and Nitrogen Compositions of Shale Oil. Fuel 1985, 64 (1), 9-14 DOI: 10.1016/0016-2361(85)90269-8.

(62) Luik, H.; Lindaru, E.; Vink, N.; Maripuu, L. Upgrading of Estonian Shale Oil Distillation Fractions. 1. Hydrogenation of the "diesel Fraction." Oil Shale 1999, 16 (2), 141-148.

(63) Landau, M. V.; Herskowitz, M.; Givoni, D.; Laichter, S.; Yitzhaki, D. Medium-Severity Hydrotreating and Hydrocracking of Israeli Shale Oil. 1. Novel Catalyst Systems. Fuel 1996, 75 (7), 858-866 DOI: 10.1016/0016-2361(96)00017-8.

(64) Williams, P. T.; Chishti, H. M. Reaction of Nitrogen and Sulphur Compounds during Catalytic Hydrotreatment of Shale Oil. Fuel 2001, 80 (7), 957-963 DOI: 10.1016/S0016-2361(00)00189-7.

(65) Yu, H.; Li, S.; Jin, G. Catalytic Hydrotreating of the Diesel Distillate from Fushun Shale Oil for the Production of Clean Fuel. Energy Fuels 2010, 24 (8), 4419-4424 DOI: 10.1021/ef100531u.

(66) Tang, X.; Li, S.; Yue, C.; He, J.; Hou, J. LUMPING KINETICS OF HYDRODESULFURIZATION AND HYDRODENITROGENATION OF THE MIDDLE DISTILLATE FROM CHINESE SHALE OIL. Oil Shale 2013, 30 (4), 517 DOI: 10.3176/oil.2013.4.05.

(67) Aarna, I.; Goelzer, A. Progress towards Installation of the Narva Shale Oil Upgrader Plant in Estonia. In 30th Oil Shale Symposium; Colorado School of Mines, Golden, CO, USA, 2010.

(68) Guo, S. H. The Chemistry of Shale Oil and Its Refining. In Coal, Oil Shale Natural Bitumen, Heavy Oil and Peat - Vol. II; Publishers Company Limited, 2009; Vol. 2, pp 94-106.

(69) Järvik, O.; Oja, V. Molecular Weight Distributions and Average Molecular Weights of Pyrolysis Oils from Oil Shales: Literature Data and Measurements by SEC and ASAP MS for Oils from Four Different Deposits. Energy Fuels 2016 DOI: 10.1021/acs.energyfuels.6b02452.

(70) Oja, V.; Elenurm, A.; Rohtla, I.; Tali, E.; Tearo, E.; Yanchilin, A. Comparison of Oil Shales from Different Deposits: Oil Shale Pyrolysis and Co-Pyrolysis with Ash. Oil Shale 2007, 24 (2), 101-108.

(71) Baird, Z. S.; Oja, V.; Järvik, O. Distribution of Hydroxyl Groups in Kukersite Shale Oil: Quantitative Determination Using Fourier Transform Infrared (FT-IR) Spectroscopy. Applied Spectroscopy 2015, 69 (5), 555-562 DOI: 10.1366/14-07705.

(72) Derenne, S.; Largeau, C.; Casadevall, E.; Sinninghe Damsté, J. S.; Tegelaar, E. W.; de Leeuw, J. W. Characterization of Estonian Kukersite by Spectroscopy and Pyrolysis: Evidence for Abundant Alkyl 
Phenolic Moieties in an Ordovician, Marine, Type II/I Kerogen. Organic Geochemistry 1990, 16 (4), 873-888 DOI: 10.1016/0146-6380(90)90124-I.

(73) Oja, V.; Rooleht, R.; Baird, Z. S. Physical and Thermodynamic Properties of Kukersite Pyrolysis Shale Oil: Literature Review. Oil Shale 2016, 33 (2), 184-197 DOI: 10.3176/oil.2016.2.06.

(74) Golubev, N. Solid Oil Shale Heat Carrier Technology for Oil Shale Retorting. Oil Shale 2003, 20 (3), 324-332.

(75) Kogerman, P. N. On the Chemistry of the Estonian Oil Shale "Kukersite."; Oil Shale Research Laboratory: Tartu, Estonia, 1931.

(76) Coates, J. Interpretation of Infrared Spectra, A Practical Approach. In Encyclopedia of Analytical Chemistry; John Wiley \& Sons, Ltd, 2006.

(77) Baird, Z. S.; Oja, V. Predicting Fuel Properties Using Chemometrics: A Review and an Extension to Temperature Dependent Physical Properties by Using Infrared Spectroscopy to Predict Density. Chemometrics and Intelligent Laboratory Systems 2016, 158, 41-47.

(78) Saajanlehto, M.; Uusi-Kyyny, P.; Alopaeus, V. A Modified Continuous Flow Apparatus for Gas Solubility Measurements at High Pressure and Temperature with Camera System. Fluid Phase Equilibria 2014, 382, 150-157 DOI: 10.1016/j.fluid.2014.08.035.

(79) National Institute of Standards and Technology. http://webbook.nist.gov/chemistry/fluid/ (accessed Feb 6, 2017).

(80) Evaluation of Measurement Data - Supplement 1 to the "Guide to the Expression of Uncertainty in Measurement" - Propagation of Distributions Using a Monte Carlo Method; Joint Committee for Guides in Metrology, 2008.

(81) Simnick, J. J.; Sebastian, H. M.; Lin, H.-M.; Chao, K.-C. Solubility of Hydrogen in Toluene at Elevated Temperatures and Pressures. J. Chem. Eng. Data 1978, 23 (4), 339-340 DOI: 10.1021/je60079a023.

(82) Riazi, M. R.; Roomi, Y. A. A Method to Predict Solubility of Hydrogen in Hydrocarbons and Their Mixtures. Chemical Engineering Science 2007, 62 (23), 6649-6658 DOI: 10.1016/j.ces.2007.08.005.

(83) Yaws, C. L. Yaws' Critical Property Data for Chemical Engineers and Chemists; Knovel, 2014.

(84) Riazi, M. R. Characterization and Properties of Petroleum Fractions; ASTM International, 2005. 